\title{
Ovicidal and larvicidal potential of Rosmarinus officinalis to control gastrointestinal nematodes of sheep
}

Potencial ovicida e larvicida de Rosmarinus officinalis para controle de nematódeos gastrintestinais de ovinos

Natália Berne Pinto ${ }^{1}$; ; Leonardo Mortagua de Castroํㅜ Rosária Helena Machado Azambuja ${ }^{1}$;

Gabriela de Almeida Capella ${ }^{1}$; Micaele Quintana de Moura ${ }^{1}$; Wesley Douglas Tertoํㅜ Rogério Antonio Freitag²;

Sabrina Taiza Jeske'; Marcos Marreiro Villela ${ }^{1}$; Marlete Brum Cleff'; Fábio Pereira Leivas Leite ${ }^{3}$

\begin{abstract}
${ }^{1}$ Laboratório de Helmintologia, Departamento de Microbiologia e Parasitologia, Instituto de Biologia, Universidade Federal de Pelotas - UFPel, Pelotas, RS, Brasil

${ }^{2}$ Laboratório de Química, Centro de Ciências Químicas, Farmacêuticas e de Alimentos, Universidade Federal de Pelotas - UFPel, Pelotas, RS, Brasil

${ }^{3}$ Laboratório de Microbiologia, Biotecnologia, Centro de Desenvolvimento Tecnológico, Universidade Federal de Pelotas - UFPel, Pelotas, RS, Brasil
\end{abstract}

Received May 29, 2019

Accepted July 10, 2019

\begin{abstract}
Gastrointestinal Nematode Infection (GIN) are the main constraint to the production of small ruminants. Studies of medicinal plants have been an important alternative in the effort to control these parasites. Therefore, the purpose of this study was to evaluate the in vitro ovicidal and larvicidal activity of essential oil of Rosmarinus officinalis. The oil was extracted, analyzed by gas chromatography and tested on GIN eggs and larvae in six concentrations, $227.5 \mathrm{mg} / \mathrm{mL}$, $113.7 \mathrm{mg} / \mathrm{mL}, 56.8 \mathrm{mg} / \mathrm{mL}, 28.4 \mathrm{mg} / \mathrm{mL}, 14.2 \mathrm{mg} / \mathrm{mL}$ and $7.1 \mathrm{mg} / \mathrm{mL}$. To determine the ovicidal activity, GIN eggs were recovered from sheep feces and incubated for $48 \mathrm{~h}$ with different concentrations of the oil. For the evaluation of larval migration, third-stage larvae (L3) were obtained by fecal culture, and associated with the essential oil for $24 \mathrm{~h}$ at the same concentrations, after which they were left for another 24 hours on microsieves, followed by the count of migrating and non-migrating larvae. The assays of $R$. officinalis oil showed a significant ( $<<0.05$ ) $97.4 \%$ to $100 \%$ inhibition of egg hatching and a significant $(\mathrm{p}<0.05) 20 \%$ to $74 \%$ inhibition of larval migration. The main constituent revealed by gas chromatography was Eucalyptol. The results indicate that $R$. officinalis essential oil has ovicidal and larvicidal activity on sheep GINs.
\end{abstract}

Keywords: Helminths, in vitro, phytotherapeutics, ruminants.

\section{Resumo}

As infecçôes por nematódeos gastrintestinais (ING) constituem a maior limitação à produção de pequenos ruminantes. $\mathrm{Na}$ busca do controle desses parasitos, estudos com plantas medicinais têm sido uma importante alternativa. Visto isto, o estudo desenvolvido teve como objetivo avaliar a ação ovicida e larvicida in vitro do óleo essencial de Rosmarinus officinalis. O óleo foi extraído, analisado por cromatografia gasosa e testado sobre ovos e larvas de ING em seis concentraçóes, $227,5 \mathrm{mg} / \mathrm{mL} ; 113,7 \mathrm{mg} / \mathrm{mL} ; 56,8 \mathrm{mg} / \mathrm{mL} ; 28,4 \mathrm{mg} / \mathrm{mL} ; 14,2 \mathrm{mg} / \mathrm{mL} ; 7,1 \mathrm{mg} / \mathrm{mL}$. Para determinar a ação ovicida, ovos de ING foram recuperados de fezes de ovinos e incubados por $48 \mathrm{~h}$ com as diferentes concentraçóes do óleo. Na avaliação da migração das larvas, as larvas de terceiro estágio (L3) foram obtidas por coprocultura, e associadas ao óleo essencial por $24 \mathrm{~h}$ nas mesmas concentraçóes, permanecendo por mais $24 \mathrm{~h}$ em microtamises, seguindo-se a contagem de larvas que migraram e que não migraram. Os testes in vitro com o óleo de $R$. officinalis mostraram o nível de significância $(\mathrm{p}<0.05)$ 97,4\% a 100\% na inibição da eclodibilidade e $20 \%$ a $74 \%$ na inibição da migraçáo das larvas. Na análise por cromatografia gasosa o constituinte majoritário foi o eucaliptol. Os resultados apresentados mostram que o óleo essencial de $R$. officinalis possui ação ovicida e larvicida sobre ING de ovinos.

Palavras-chave: Helmintos, in vitro, fitoterápicos, ruminantes. 


\section{Introduction}

Sheep meat production has been strongly promoted and its structure has been modified to meet market demands, aiming for greater productivity in less space. To this end, sheep flocks have been concentrated in small areas and animals selected based on their production of meat. This new reality of production, coupled with inefficient management, has caused gastrointestinal nematodes (GINs) to become the main obstacle to sheep production (AMARANTE et al., 2014).

Attempts to reduce losses have led to significantly increased frequency and doses applied in anthelmintic treatments, causing irreversible resistance of GIN to practically all the available active ingredients (SALGADO \& SANTOS, 2016). Haemonchus contortus stands out among these parasites, mainly due to its hematophagous nature and high prolificacy of females (GETACHEW et al., 2007).

Worldwide studies that have focused on devising new strategies to combat these nematodes include management procedures involving different ruminant species, rotational grazing, crop-livestock integration, genetic selection of animals, the use of fungi and bacteria in biological control, herbal medicines, and vaccine production (MOLENTO et al., 2013; SINOTT et al., 2012).

In recent years, studies involving plants have stood out among the lines of research that seek alternative methods to control ruminant parasites. These studies have revealed promising anthelmintic activity on gastrointestinal parasites of sheep (CAMURCA-VASCONCELOS et al., 2007; YOSHIHARA et al., 2014; RIBEIRO et al., 2014; MARIE-MAGDELEINE et al., 2014; MACEDO et al., 2015).

Rosmarinus officinalis, which belongs to the family Lamiaceae, is commonly known as rosemary. This plant is widely used in cooking, but studies have shown that its essential oil has antibacterial and antifungal properties (OLUWATUYI et al., 2004; GENENA et al., 2008). Thus, in view of the severe problem of drug resistance allied with the consumer's demand for food devoid of chemical residues, there is an undeniable need to find sustainable alternatives for the control of GIN in sheep. Therefore, this study aims to evaluate the in vitro activity of $R$. officinalis oil on eggs and larvae of gastrointestinal parasitic nematodes of sheep.

\section{Materials and Methods}

\section{Production of essential oil}

Rosmarinus officinalis essential oil was produced from plant material purchased from a commercial distributor (Luar Sul Alimentos) with certified quality and provenance. The dried leaves were subjected to steam extraction in a Clevenger apparatus for 4 hours. The essential oil was then obtained by hydrodistillation (1.5L distilled water $100 \mathrm{~g}$ plant), dried with P.A. grade anhydrous sodium sulfate, and stored in an amber flask at $-18^{\circ} \mathrm{C}$ until use.

The $R$. officinalis essential oil was analyzed by gas chromatography coupled to mass spectrometry (GC-MS) (CHIARADIA et al., 2008) and its compounds were analyzed based on the NIST08 GC/MS library. The chemical composition of the essential oil used in this study was determined by a Schimadzu QP2010 GC/MS apparatus, equipped with split/splitless injector with Rtx-5MS RESTEK capillary column ( $30 \mathrm{mx} 0.25 \mathrm{~mm} \times 0.25 \mu \mathrm{m})$, graphite stations: Helium carrier gas, electron impact fragments in energy of $70 \mathrm{~V}$, flow rate of $1.2 \mathrm{~mL} / \mathrm{min}, 1: 10$ split, injected volume of $1 \mu \mathrm{L}$ sample. Programmed oven temperature: at an initial temperature of $40{ }^{\circ} \mathrm{C}$, with a heating temperature of $5^{\circ} \mathrm{C} / \mathrm{min}$ to $280{ }^{\circ} \mathrm{C}$, maximum temperature of $58^{\circ} \mathrm{C}$, the injector temperature being $58^{\circ} \mathrm{C}$ and the interface $200{ }^{\circ} \mathrm{C}$. The oil was diluted in hexane, P.A.

In preparation for the tests, essential oil was diluted in distilled water and $1 \%$ Tween 80 , as follows: $227.5 \mathrm{mg} / \mathrm{mL}, 113.7 \mathrm{mg} / \mathrm{mL}$, $56.8 \mathrm{mg} / \mathrm{mL}, 28.4 \mathrm{mg} / \mathrm{mL}, 14.2 \mathrm{mg} / \mathrm{mL}$, and $7.1 \mathrm{mg} / \mathrm{mL}$ corresponding, respectively, to concentrations of $25 \%, 12.5 \%, 6.25 \%, 3.12 \%$, $1.56 \%$ and $0.78 \%$.

\section{Obtaining eggs}

GIN eggs were recovered from feces collected directly from the rectal ampulla of sheep with natural mixed infection. The fecal samples were processed immediately, first by maceration and homogenization with distilled water at $40{ }^{\circ} \mathrm{C}$. Next, they were passed through $1 \mathrm{~mm}, 105 \mu \mathrm{m}$, and $55 \mu \mathrm{m}$ mesh sieves in order to retain the largest particles of fecal matter. The remaining material was sifted through a $25 \mu \mathrm{m}$ mesh sieve where the eggs were retained, recovered and centrifuged three times $(203 \mathrm{~g}$ for 5 minutes) with distilled water, and the supernatant was discarded. A final centrifugation was performed using supersaturated salt solution to float the eggs, and this supernatant was discarded in the $25 \mu \mathrm{m}$ mesh sieve for washing in distilled water (HUBERT \& KERBOEUF, 1992).

\section{Inhibition of Hatchability (IH) assay}

The hatchability inhibition assay was performed based on the technique described by Coles et al. (1992) with modifications, using approximately 150 eggs from the test solutions in polyethylene 24-well plates. This involved the formation of four groups as follows: Group 1: Rosemary essential oil at concentrations of $227.5 \mathrm{mg} / \mathrm{mL} ; 113.7 \mathrm{mg} / \mathrm{mL} ; 56.8 \mathrm{mg} / \mathrm{mL} ; 28.4 \mathrm{mg} / \mathrm{mL} ; 14.2 \mathrm{mg} / \mathrm{mL}$; and $7.1 \mathrm{mg} / \mathrm{mL}$; Group 2: Negative control with distilled water; Group 3: Positive control with thiabendazole $0.025 \mathrm{mg} / \mathrm{mL}$; Group 4: control of physical activity with Mineral Oil; and Group 5: with $1 \%$ Tween 80 . All the assays, which involved incubation for 48 hours at $28{ }^{\circ} \mathrm{C}$ and $80 \%$ relative humidity $(\mathrm{RH})$, were performed in triplicate. After this period, the readings were carried out under an inverted microscope, by counting the eggs and larvae contained in each well. The mean inhibition of hatchability (IH) of each treatment was determined according to the equation described by Camurça-Vasconcelos et al. (2007): \% IH = number of larvae/number of larvae + number of eggs X 100 .

\section{Obtaining larvae}

Fecal samples were collected directly from the rectal ampulla of sheep with natural mixed infection by gastrointestinal nematodes. The samples were processed to identify positive ones by quantifying the eggs using the technique described by Gordon \& Whitlock (1939) with modifications. Positive samples were incubated for 
7 days at $28^{\circ} \mathrm{C}$ and $\mathrm{RH}$ higher than $80 \%$, after which third-stage larvae (L3) were recovered (ROBERTS \& O'SULLIVAN, 1950), counted and identified (UENO \& GONÇALVES, 1988).

\section{Inhibition of Larval Migration (ILM) assay}

The IML assay was performed as proposed by Demeler et al. (2010), with modifications. Accordingly, the larvae were first placed on $25 \mu \mathrm{m}$ sieve membranes to migrate for approximately one hour, after which viable larvae were selected and placed in six-well polyethylene plates. After this initial selection, the L3 were placed in $0.6 \%$ of the unsheathing solution $(2 \%$ sodium hypochlorite) for approximately $20 \mathrm{~min}$. They were then washed three times by centrifugation in distilled water $(203 \mathrm{~g}$ for $2 \mathrm{~min}$ ), and the finally adjusted to obtain a concentration of 150 larvae in $100 \mu \mathrm{L}$.

One hundred microliters of the larval solution were then added to the first and third lines of the 24-well plates and incubated for 24 hours at $28^{\circ} \mathrm{C}$ and $80 \% \mathrm{RH}$, with $900 \mu \mathrm{l}$ of solution with oil at the concentrations of $227.5 \mathrm{mg} / \mathrm{mL} ; 113.7 \mathrm{mg} / \mathrm{mL} ; 56.8 \mathrm{mg} / \mathrm{mL}$; $28.4 \mathrm{mg} / \mathrm{mL} ; 14.2 \mathrm{mg} / \mathrm{mL}$; and $7.1 \mathrm{mg} / \mathrm{mL}$. After this period, the content of each well containing L3 was transferred to $25 \mu \mathrm{m}$ sieve membranes placed in another 24-well polyethylene plate, which was incubated at $28{ }^{\circ} \mathrm{C}$ for 24 hours. The membranes were then removed and the content retained on them were placed in the wells of the second and fourth lines of the plate, after which a count was made under an inverted microscope of the larvae that migrated and those that were retained on the sieve membranes. The same procedure was performed with the controls, using distilled water, mineral oil, Tween buffer, and an anthelmintic drug $(0.025 \mathrm{mg} / \mathrm{mL}$ of Levamisole). All the assays were performed in triplicate.

Analysis of Variance (ANOVA), followed by multiple comparison Tukey's test, was applied at a 5\% probability level to analyze the data on inhibition of hatchability ( $\mathrm{IH}$ ) and inhibition of larval migration (ILM), using GraphPad Prism version 7.0 software. The half maximal inhibitory concentration $\left(\mathrm{IC}_{50}\right)$, which can inhibit larval migration by $50 \%$, was determined from the dose-response curve with a $95 \%$ confidence interval, using the program GraphPad Prism v. 5.0 for Windows.

This study was approved by the Ethics Committee for Animal Experimentation (CEEA) of the Federal University of Pelotas UFPel, under Protocol No. 3897.

\section{Results}

The chromatographic evaluation of $R$. officinalis essential oil revealed 18 different compounds (Table 1), and the three major ones were eucaliptol, bornanone and alpha-pinene, which together represent more than $70 \%$ of the components of the essential oil.

The inhibitory effect of $R$. officinalis essential oil on hatchability varied from $97.4 \%$ to $100 \%$ at all the tested dilutions $(227.5 \mathrm{mg} / \mathrm{mL}$; $113.7 \mathrm{mg} / \mathrm{mL} ; 56.8 \mathrm{mg} / \mathrm{mL} ; 28.4 \mathrm{mg} / \mathrm{mL} ; 14.2 \mathrm{mg} / \mathrm{mL}$; and $7.1 \mathrm{mg} / \mathrm{mL}$ ). The oil's inhibitory effect on larval migration ranged from $70 \%$ to $74 \%$ at the two highest tested concentrations, respectively, and from $20 \%$ to $58 \%$ at the other concentrations (Table 2). Inhibition of the distilled water, Tween and mineral oil controls, in both tests, was less than $10 \%$.
Table 1. Rosmarinus officinalis essential oil compounds identified by gas chromatography coupled to mass spectrometry.

\begin{tabular}{lc}
\hline \multicolumn{2}{c}{ Gas Chromatography (\%) } \\
\hline Eucalyptol (1.8-cineole) & 42.11 \\
(+)-2-Bornanone & 16.37 \\
alpha.-Pinene & 14.76 \\
Isoborneol & 5.73 \\
alpha.-Terpineol & 5.40 \\
Camphene & 3.87 \\
o-Cymene & 2.69 \\
Bicyclo[3.1.1]heptane, 6,6-dimethyl-2-methylene-, (1S) & 2.08 \\
1,6-Octadien-3-ol, 3,7-dimethyl & 1.70 \\
beta.-Myrcene & 1.38 \\
Terpinen-4-ol & 1.23 \\
Bornyl acetate & 0.84 \\
Caryophyllene & 1.00 \\
gamma.-Terpinene & 0.37 \\
Phenol, 2-methyl-5-(1-methylethyl) & 0.19 \\
Humulene & 0.15 \\
Methyleugenol & 0.07 \\
Thymol & 0.05 \\
\hline
\end{tabular}

Table 2. Efficacy of essential oil of Rosmarinus officinalis in vitro to inhibit hatchability (IE) and migration of larvae (IM) from gastrointestinal nematodes of sheep.

\begin{tabular}{lcc}
\hline \multicolumn{1}{c}{ Treatment } & $\begin{array}{c}\text { Inhibition of } \\
\text { Hatchability (\%) }\end{array}$ & $\begin{array}{c}\text { Inhibition of Larval } \\
\text { Migration (\%) }\end{array}$ \\
\hline Control & $1.1^{\mathrm{c}}$ & $6.9^{\mathrm{f}}$ \\
Tween 80 & $5.3^{\mathrm{b}}$ & $10^{\text {ef }}$ \\
Mineral Oil & $4.5^{\mathrm{bc}}$ & $8.3^{\text {ef }}$ \\
$\mathrm{AH}$ & $100^{\mathrm{a}}$ & $99.5^{\mathrm{a}}$ \\
$227.5 \mathrm{mg} / \mathrm{mL}$ & $100^{\mathrm{a}}$ & $74^{\mathrm{b}}$ \\
$113.7 \mathrm{mg} / \mathrm{mL}$ & $100^{\mathrm{a}}$ & $70.1^{\mathrm{bc}}$ \\
$56.8 \mathrm{mg} / \mathrm{mL}$ & $100^{\mathrm{a}}$ & $55.3^{\mathrm{c}}$ \\
$28.4 \mathrm{mg} / \mathrm{mL}$ & $100^{\mathrm{a}}$ & $35.6^{\mathrm{d}}$ \\
$14.2 \mathrm{mg} / \mathrm{mL}$ & $98.3^{\mathrm{a}}$ & $23^{\mathrm{de}}$ \\
$7.1 \mathrm{mg} / \mathrm{mL}$ & $97.4^{\mathrm{a}}$ & $20^{\text {def }}$ \\
$\mathrm{MSD}$ & 3.45 & 16.08 \\
\hline
\end{tabular}

AH: antihelmintic; MSD: Minimum Significant Difference Tukey 5\%; Values with different lowercase letters in same column indicate significant differences $(\mathrm{p}<0.05)$ between concentrations.

A statistical analysis of the IH showed no difference between treatments, but all differed statistically from the control. The same analysis of ILM revealed that the effect of the two highest concentrations was statistically the same, but differed from the other treatments and the control. The minimum concentration of $R$. officinalis essential oil needed to inhibit $50 \%$ of hatchability $\left(\mathrm{IC}_{50}\right)$ was $0.5181 \mathrm{mg} / \mathrm{mL}$, while the $\mathrm{IC}_{50}$ of larval inhibition was $62.17 \mathrm{mg} / \mathrm{mL}$.

The parasite genera identified in the fecal cultures were Haemonchus spp. (79\%), Ostertagia spp. (18\%) and Trichostrongylus spp. (3\%). 


\section{Discussion}

Plants of the Lamiaceae family are among the most widely studied for phytotherapeutic purposes, and among the species of this family, $R$. officinalis has shown nematicidal activity on plant nematodes (WANG et al., 2012). The nematicidal effect of essential oils is due to multiple factors that are deleterious to metabolic activity, to alterations of cellular membrane permeability, and to destructuring of the nervous system (OKA et al., 2000).

The use of plants as an alternative for the control of gastrointestinal nematodes of sheep has been reported in different regions of the world (RAJESWARI, 2014). The essential oils are prominent in this line of research and are characterized by being complex compounds that can contain from 20 to 60 compounds in different concentrations, being the major components the probable determinants of the biological action of the oil (SINTIM et al., 2015).

In chromatographic analyses, different compounds have been identified in $R$. officinalis essential oil. Among them, eucaliptol (1,8-cineole) have been described as major compounds (42.8\%), according to different authors Jiang et al. (2011), Santoyo et al. (2005) and Okoh et al. (2010). Bozin et al. (2007) and Gachkar et al. (2007). The monoterpene 1,8-cineol (eucalyptol) has been reported to have action on larvae of the Anisakis simplex nematode (NAVARRO et al., 2008) and also against Dactylogyrus minutus (Monogenea) parasites in fish (ZORAL et al., 2017).

In the present study, where Haemonchus was the most prevalent nematode (79\%), suggest that the essential oil of $R$. officinalis acts on gastrointestinal nematodes with $100 \%$ inhibition of hatchability (IH) at the highest concentration $(227.5 \mathrm{mg} / \mathrm{mL})(\mathrm{p}<0.05)$ to the concentration of $7.1 \mathrm{mg} / \mathrm{mL}(97.4 \%)$. Similar results were reported by Macedo et al. (2009), studying Eucalyptus globulus essential oil, whose major constituent is also 1,8-cineol (eucalyptol), observed $99.3 \%$ egg hatching was inhibited at concentration of $21.75 \mathrm{mg} / \mathrm{mL}$.

In the literature, there are reports of the toxic effect of $R$. officinalis essential oil against protozoa (PEREIRA et al., 2017) and ectoparasites (MARTINEZ-VELAZQUEZ et al., 2011) however, studies on the action of nematode of domestic ruminants are still scarce.

The results of the essential oil effect of $R$. officinalis on inhibition of larval migration (ILM) show that the concentration required to obtain this activity satisfactorily is higher than that required for inhibition of hatchability (IH), the maximum of ILM (74\%) was achieved in the concentration of $227.5 \mathrm{mg} / \mathrm{mL}$, while in the HI the lowest concentration was already efficient (97.4\%). Similar effect was observed with Melaleuca alternifolia, which at a concentration of $56 \mathrm{mg} / \mathrm{mL}$ and $3.5 \mathrm{mg} / \mathrm{mL}$ inhibited $88 \%$ larval migration and $100 \%$ hatchability of $H$. contortus, respectively (GRANDO et al., 2016). The concentration required to inhibit larval migration is higher than that needed to inhibit hatchability (GRANDO et al., 2016; YOSHIHARA et al., 2014; QI et al., 2015). This is probably due to the fact that infecting larvae can survive in the environment exposed for long periods to deleterious weathering. The survival of these larvae in the environment is attributed to their double cuticle and the process they undergo, called anhydrobiosis, which severely reduces their metabolic activity, thereby prolonging their survival (AMARANTE et al.,
2014). The $\mathrm{LC}_{50}$ for hatchability was similar, i.e., $0.43 \mathrm{mg} / \mathrm{mL}$ for $M$. alternifolia and $0.51 \mathrm{mg} / \mathrm{mL}$ for $R$. officinalis.

Macedo et al. (2015), who evaluated the potential of essential oil of Cymbopogon citratus inhibiting the hatchability of $H$. contortus, reported $99.5 \%$ of inhibition at a concentration of $1.25 \mathrm{mg} / \mathrm{mL}$. Their result is close to that of $R$. officinalis essential oil, observed in this study, which was $97.4 \%$ when tested at the highest concentration $(7.1 \mathrm{mg} / \mathrm{mL})$. One can suggest that the dissimilar results of these studies can be attributed to fact that they involved different plants, as well as different parasites. In our study, we evaluated three genera of gastrointestinal nematodes, similar to those found in the field, since sheep commonly have mixed infestations, whereas the effect of Cymbopogon citratus essential oil was evaluated only on $H$. contortus. This difference in product efficacy among genera of gastrointestinal parasitic nematodes of ruminants has been described even with commercial anthelmintics, suggesting that the species Haemonchus is more sensitive than other nematodes (NOVA et al., 2014).

\section{Conclusions}

Rosmarinus officinalis essential oil showed ovicidal and larvicidal activity in vitro on gastrointestinal nematodes, constituting a promising alternative for use as a phytotherapeutic agent for the control of intestinal nematodes of sheep.

\section{References}

Amarante AFTD, Ragozo A, Silva BFD. Os parasitas de ovinos. São Paulo; Editora Unesp Digital; 2014. http://dx.doi.org/10.7476/9788568334423.

Bozin B, Mimica-Dukic N, Samojlik I, Jovin E. Antimicrobial and antioxidant properties of rosemary and sage (Rosmarinus officinalis L. and Salvia officinalis L., Lamiaceae) essential oils. J Agric Food Chem 2007; 55(19): 7879-7885. http://dx.doi.org/10.1021/jf0715323. PMid:17708648.

Camurça-Vasconcelos ALF, Bevilaqua CML, Morais SM, Maciel MV, Costa CTC, Macedo ITF, et al. Anthelmintic activity of Croton zehntneri ans Lippia sidoides essential oils. Vet Parasitol 2007; 148(3-4): 288-294. http://dx.doi.org/10.1016/j.vetpar.2007.06.012. PMid:17629623.

Chiaradia MC, Collins CH, Jardim ICSF. O estado da arte da cromatografia associada à espectrometria de massas acoplada à espectrometria de massas na análise de compostos tóxicos em alimentos. Quim Nova 2008; 31(3): 623-636. http://dx.doi.org/10.1590/S0100-40422008000300030.

Coles GC, Bauer C, Borgsteede FHM, Geerts S, Klei TR, Taylor MA, et al. World Association for the Advancement of Veterinary Parasitology (W.A.A.V.P.) methods for the detection of anthelmintic resistance in nematodes of veterinary importance. Vet Parasitol 1992; 44(1-2): 35-44. http://dx.doi.org/10.1016/0304-4017(92)90141-U. PMid:1441190.

Demeler J, Küttler U, El-Abdellati A, Stafford K, Rydzik A, Varady $\mathrm{M}$, et al. Standardization of the larval migration inhibition test for the detection of resistance to ivermectin in gastrointestinal nematodes of ruminants. Vet Parasitol 2010; 174(1-2): 58-64. http://dx.doi.org/10.1016/j. vetpar.2010.08.020. PMid:20850930.

Gachkar L, Yadegari D, Rezaei MB, Taghizadeh M, Astaneh SA, Rasooli I. Chemical and biological characteristics of Cuminum cyminum and Rosmarinus officinalis essential oils. Food Chem 2007; 102(3): 898-904. http://dx.doi.org/10.1016/j.foodchem.2006.06.035. 
Genena AK, Hense H, Smânia A Jr, Souza SM. Rosemary (Rosmarinus officinalis) - a study of the composition, antioxidant and antimicrobial activities of extracts obtained with supercritical carbon dioxide. Food Sci Technol (Campinas) 2008; 28(2): 463-469. http://dx.doi.org/10.1590/ S0101-20612008000200030

Getachew T, Dorchies P, Jacquiet P. Trends and challenges in the effective and sustainable control of Haemonchus contortus infection in sheep. Parasite 2007; 14(1): 3-14. http://dx.doi.org/10.1051/parasite/2007141003. PMid:17432053.

Gordon HM, Whitlock HV. A new technique for counting nematode eggs in sheep faeces. J Counc Sci Ind Res 1939; 12(1): 50-52.

Grando TH, Sá MF, Baldissera MD, Oliveira CB, Souza ME, Raffin $\mathrm{RP}$, et al. In vitro activity of essential oils of free and nanostructured Melaleuca alternifolia and of terpinen-4-ol on eggs and larvae of Haemonchus contortus.J Helminthol 2016; 90(3): 377-382. http://dx.doi.org/10.1017/ S0022149X15000401. PMid:26096177.

Hubert J, Kerboeuf D. A microlarval development assay for the detection of anthelmintic resistance in sheep nematodes. Vet Rec 1992; 130(20): 442-446. http://dx.doi.org/10.1136/vr.130.20.442. PMid:1621342.

Jiang Y, Wu N, Fu Y, Wang W, Luo M, Zhao CJ, et al. Chemical composition and antimicrobial activity of the essential oil of Rosemary. Environ Toxicol Pharmacol 2011; 32(1): 63-68. http://dx.doi.org/10.1016/j. etap.2011.03.011. PMid:21787731.

Macedo ITF, Bevilaqua CML, Oliveira LMB, Camurça-Vasconcelos ALF, Vieira LS, Oliveira FR, et al. Atividade ovicida e larvicida in vitro do óleo essencial de Eucalyptus globulus sobre Haemonchus contortus. Rev Bras Parasitol Vet 2009; 18(3): 62-66. http://dx.doi.org/10.4322/ rbpv.01803011. PMid:19772778.

Macedo ITF, Oliveira LMB, Ribeiro WLC, Santos JML, Silva KC, Araújo JV Fo, et al. Anthelmintic activity of Cymbopogon citratus against Haemonchus contortus. Rev Bras Parasitol Vet 2015; 24(3): 268-275. http:// dx.doi.org/10.1590/S1984-29612015059. PMid:26444058.

Marie-Magdeleine C, Udino L, Philibert L, Bocage B, Archimede H. In vitro effects of Musa x paradisiaca extracts on four developmental stages of Haemonchus contortus. Res Vet Sci 2014; 96(1): 127-132. http://dx.doi. org/10.1016/j.rvsc.2013.12.004. PMid:24382490.

Martinez-Velazquez M, Rosario-Cruz R, Castillo-Herrera G, FloresFernandez JM, Alvarez AH, Lugo-Cervantes E. Acaricidal effect of essential oils from Lippia graveolens (Lamiales: Verbenaceae), Rosmarinus officinalis (Lamiales: Lamiaceae), and Allium sativum (Liliales: Liliaceae) Against Rhipicephalus (Boophilus) microplus (Acari: Ixodidae). J Med Entomol 2011; 48(4): 822-827. http://dx.doi.org/10.1603/ME10140. PMid:21845941.

Molento MB, Veríssimo CJ, Amarante AT, van Wyk J, Chagas ACS, Araújo $\mathrm{JV}$, et al. Alternativas para o controle de nematoides gastrintestinais de pequenos ruminantes. Arq Inst Biol (Sao Paulo) 2013; 80(2): 253-263. http://dx.doi.org/10.1590/S1808-16572013000200018.

Navarro MC, Noguera MA, Romero MC, Montilla MP, Selgas JG, Valero A. Anisakis simplex s.l.: larvicidal activity of various monoterpenic derivatives of natural origin against L3 larvae in vitro and in vivo. Exp Parasitol 2008; 120(4): 295-299. http://dx.doi.org/10.1016/j.exppara.2008.07.014. PMid:18713626.

Nova LEV, Costa ME, Melo PGCF, Cunha LFC Fo, Barca FA Jr, Silva LC, et al. Resistência de nematoides aos anti-helmínticos nitroxinil 34\% e ivermectina $1 \%$ em rebanho ovino no município de São João do Ivaí, Paraná. Rev Bras Hig Sanid Anim 2014; 8(1): 159-171.

Oka Y, Nacar S, Putievsky E, Ravid U, Yaniv Z, Spiegel Y. Nematicidal activity of essential oils and their components against the root-knot nematode. Phytopathology 2000; 90(7): 710-715. http://dx.doi.org/10.1094/ PHYTO.2000.90.7.710. PMid:18944489.

Okoh OO, Sadimenko AP, Afolayan AJ. Comparative evaluation of the antibacterial activities of the essential oils of Rosmarinus officinalis L. obtained by hydrodistillation and solvent free microwave extraction methods. Food Chem 2010; 120(1): 308-312. http://dx.doi.org/10.1016/j. foodchem.2009.09.084

Oluwatuyi M, Kaatz GW, Gibbons S. Antibacterial and resistance modifying activity of Rosmarinus officinalis. Phytochemistry 2004; 65(24): 3249-3254. http://dx.doi.org/10.1016/j.phytochem.2004.10.009. PMid:15561190.

Pereira PS, Maia AJ, Tintino SR, Oliveira-Tintino CDM, Raulino ISS, Vega MC, et al. Trypanocide, antileishmania and cytotoxic activities of the essential oil from Rosmarinus officinalis $\mathrm{L}$ in vitro. Ind Crops Prod 2017; 109: 724-729. http://dx.doi.org/10.1016/j.indcrop.2017.09.030.

Qi H, Wang WX, Dai JL, Zhu L. In vitro anthelmintic activity of Zanthoxylum simulans essential oil against Haemonchus contortus. Vet Parasitol 2015; 211(3-4): 223-227. http://dx.doi.org/10.1016/j. vetpar.2015.05.029. PMid:26073109.

Rajeswari VD. Anthelmintic activity of plants: a review. Res J Phytochem 2014; 8(3): 57-63. http://dx.doi.org/10.3923/rjphyto.2014.57.63.

Ribeiro ARC, Andrade FD, Medeiros MC, Camboim AS, Pereira FA Jr, Athayde ACR, et al. Estudo da atividade anti-helmíntica do extrato etanólico de Jatropha mollissima (Pohl) Baill. (Euphorbiaceae) sob Haemonchus contortus em ovinos no semiárido paraibano. Pesq Vet Bras 2014; 34(11): 1051-1055. http://dx.doi.org/10.1590/S0100-736X2014001100002.

Roberts FHS, O'Sullivan SP. Methods for egg counts and larval cultures for strongyles infesting the gastro-intestinal tract of cattle. Aust J Agric Res 1950; 1(1): 99-102. http://dx.doi.org/10.1071/AR9500099.

Salgado JA, Santos CP. Overview of anthelmintic resistance of gastrointestinal nematodes of small ruminants in Brazil. Rev Bras Parasitol Vet 2016; 25(1): 3-17. http://dx.doi.org/10.1590/S1984-29612016008. PMid:26982560.

Santoyo S, Cavero S, Jaime L, Ibañez E, Señoráns FJ, Reglero G. Chemical composition and antimicrobial activity of Rosmarinus officinalis L. essential oil obtained via supercritical fluid extraction. J Food Prot 2005; 68(4): 790795. http://dx.doi.org/10.4315/0362-028X-68.4.790. PMid:15830672.

Sinott MC, Cunha NA Fo, Castro LLD, Lorenzon LB, Pinto NB, Capella GA, et al. Bacillus spp. toxicity against Haemonchus contortus larvae in sheep fecal cultures. Exp Parasitol 2012; 132(2): 103-108. http://dx.doi. org/10.1016/j.exppara.2012.05.015. PMid:22728159.

Sintim HY, Burkhardt A, Gawde A, Cantrell CL, Astatkie T, Obour AE, et al. Hydrodistillation time affects dill seed essential oil yield, composition, and bioactivity. Ind Crops Prod 2015; 63: 190-196. http:// dx.doi.org/10.1016/j.indcrop.2014.09.058.

Ueno H, Gonçalves PC. Manual para diagnóstico das helmintoses de ruminantes. Tokyo: Japan International Cooperation Agency; 1988.

Wang J, Pan X, Han Y, Guo D, Guo Q, Li R. Rosmarinic acid from eelgrass shows nematicidal and antibacterial activities against pine wood nematode and its carrying bacteria. Mar Drugs 2012; 10(12): 2729-2740. http://dx.doi.org/10.3390/md10122729. PMid:23201594.

Yoshihara E, Minho AP, Cardim ST, Tabacow VBD, Yamamura MH. In vitro ovicidal and larvicidal activity of condensed tannins on gastrointestinal nematode infestations in sheep (Ovis aries). Semina: Ciênc Agrár 2014; 35(6): 3173-3180. http://dx.doi.org/10.5433/1679-0359.2014v35n6p3173.

Zoral MA, Futami K, Endo M, Maita M, Katagiri T. Anthelmintic activity of Rosmarinus officinalis against Dactylogyrus minutus (Monogenea) infections in Cyprinus carpio. Vet Parasitol 2017; 247: 1-6. http://dx.doi. org/10.1016/j.vetpar.2017.09.013. PMid:29080753. 